\title{
PRESERVATION OF A HIGHER EDUCATION INSTITUTION AS A PREREQUISITE OF SOCIO-ECONOMIC DEVELOPMENT IN THE REGION
}

\section{Orshanskiy L. V.}

\section{INTRODUCTION}

The real socio-economic and spiritual development of society is the strengthening of the role of regions. As a result, the regionalization of higher education becomes relevant, which involves its adaptation to the socio-economic conditions of a specific territory, providing labor resources possessing knowledge and competencies specific to existing enterprises and organizations in the region. It should be noted that in Ukraine, the importance of regional policy in the field of higher education in recent years has increased significantly under the influence of socio-political processes. This trend is especially traced in connection with the gradual decentralization of power, the expansion of rights and powers of regions in various spheres of activity, including education.

The Ukrainian government pays a special attention to regional policy in the field of higher education, in particular, in the distribution of higher education institutions (HEI) by regions. As indicated in the informational and statistical bulletin of the results of the education industry in 2017-2018 the indicator of such a distribution is the number of universities of a certain level, which accounts for one percent of the population of the region. According to this indicative indicator, the leaders in the absolute number of III - IV levels of accreditation HEI in the given period were Dnipro, Donetsk, Kyiv, Odessa, Kharkiv and Lviv regions. The most balanced is the distribution of universities in the Kharkiv, Odesa and Zaporizhzhya regions, while significant disparities between the number of population and the number of state-owned HEI of III-IV accreditation levels are 
observed in Vinnytsa, Volyn, Luhansk, Mykolayiv, Kropyvnytskyi and Kherson regions. Several regions, including Ternopil and Khmelnytsky, have reduced this imbalance at the expense of private universities, however in the vast majority of these regions of private property ownership did not resolve this problem ${ }^{1}$.

In their development, individual regional HEI actually moved beyond the classical universities and began to evolve into regional university complexes that integrate different levels of education acquired in higher vocational schools, technical colleges, etc. Creation of such complexes in modern conditions promotes effective interaction of HEI and regions, bringing together institutions of education of different status, profile, forms of ownership and level of accreditation.

The functional structural organization of the regional university reflects the diversified nature of the region and, to a certain extent, responds to the group and individual needs of its population. Thus, the national regional higher educational institutions respond promptly to the demands of the economy of their region, therefore the classical directions of training of specialists with a higher education diploma receive a practical orientation taking into account the features of economic development of the territory. The predicted situation on the market of educational services makes regional HEI pay close attention to the formation of conditions for attracting graduates of secondary schools. This is due to the extremely aggravated demographic situation, which naturally caused a fierce competition between higher education institutions of allUkrainian and regional levels.

Regional HEI gradually become centers for providing the whole spectrum of not only educational services, but also cultural, social, ecological and other kinds of assistance to the population of the region. One of the main goals of regional HEI is to provide and multiply the

\footnotetext{
${ }^{1}$ Освіта в Україні: базові індикатори. Інформаційно-статистичний бюлетень результатів діяльності галузі освіти у 2017/2018 н. p. URL : https://mon.gov.ua/storage/app/media/nova-ukrainska-shkola/1serpkonfinformatsiyniy-byuleten.pdf
} 
human resources of the region ${ }^{2}$. Therefore, the choice of the type of regional HEI is determined by the needs of the real sector of the economy of a specific region, its potential, size, development, structure and specificity of the economy.

Hence, the problems of higher education can not be solved in isolation from the problems of socio-economic development of the state and its separate regions. On the other hand, the priority role in the formation and implementation of the innovative strategy of socio-economic development should belong to the higher education, which has the necessary intellectual potential for solving this large-scale problem. As noted in the analytical report "Regional Development and State Regional Policy in Ukraine", regional HEI in accordance with the main directions of regional innovation policy: 1) take an active part in the development and implementation of the strategy of innovation development of the region and its monitoring; 2) coordinate and implement measures of state and territorial development programs of the region; 3) participate in the development of business plans, scientific and methodological and informational provision of innovative development of the region; 4) carry out scientific and methodological support for the development of regional innovation structures, small and medium innovative enterprises, technology transfer centers, technology parks, resort poles, etc ${ }^{3}$.

\section{Drohobych Ivan Franko State Pedagogical University as the generator of innovative social and economic development of the region}

Among the diversity of regional universities a significant niche is occupied by pedagogical universities. It should be noted that the public discussion of ways of reforming pedagogical education actualizes the

\footnotetext{
2 Ржепішевська В.В. Проблеми та перспективи функціонування вищих навчальних закладів у регіональній інноваційній системі. Ефективна економіка : електронний журнал. 2013. № 3. URL : http://www.economy.nayka.com.ua/?op=1\&z=1877\#

Регіональний розвиток та державна регіональна політика в Україні : стан і перспективи змін у контексті глобальних викликів та європейських стандартів політики : аналітичний звіт. URL : https://surdp.eu/uploads/files/Analytical_Report_Main_part_UA.pdf
} 
analysis of a number of problems of the economy and management of the educational branch. In particular, it is necessary to resolve the contradiction between the need to ensure an efficient, sustainable functioning of the training system for teachers and the aggravation of the risks of ill-considered optimization of the HEI. Most clearly this contradiction is manifested at the regional level; therefore, we consider it necessary to argue the social effectiveness of the preservation and gradual transformation of the traditional system of higher pedagogical education for the region which chose the innovative way of socio-economic development. According to T. Nakonechna, the need for an integrated approach to the formation of an innovation and educational strategy of the region should meet the following requirements: taking into account the complex features of the region, promoting their conservation and development; having a systemic character; ensuring the creation of socioeconomic conditions for the introduction of innovations ${ }^{4}$.

An example of Lviv region, and, above all, the Drohobych area, in this sense is quite indicative, since it is an agro-industrial, tourist and crossborder region, which has a pronounced specificity of socio-economic and socio-cultural development of the territory. There are several groups of objective constituents that stipulate the need for a sustained link between innovation development and the presence in the Drohobych area of pedagogical education, in the system of which the main subject is a specialized HEI - Pedagogical University.

1. Territorial structure of the region. The Drohobych area occupies a rather large territory $-1217 \mathrm{~km}^{2}$, which incorporates four cities, two urbantype settlements and 74 villages. As of January 1, 2019 the population of Drohobych area amounted to 74,350 people. The administrative center is Drohobych - a city of regional significance, located on the territory of $44,5 \mathrm{~km}^{2}$ with a population of 96,612 inhabitants (together with the town of

\footnotetext{
${ }^{4}$ Наконечна Т. Ю. Регіональна інноваційна політика як фактор зростання національної економіки. Теоретичні і практичні аспекти економіки та інтелектуальної власності. 2010. Т. 1. С. 71.
} 
Stebnyk) ${ }^{5}$. As you can see, the main types of settlement in the Drohobych area are villages. In these conditions, the preservation of pedagogical education in the region solves many problems: provision of rural schools with qualified, diverse pedagogical staff, preservation of a network of small-scale schools and the formation of large secondary schools (lyceums) with specialized training, development of social infrastructure, cultural and educational environment, etc. and, as a direct consequence, the preservation of villages as the main types of settlement in the region.

2. Socio-demographic structure of the region. After the "demographic pit" of the mid-1990s in the twentieth century, in the early 2000s in the Drohobych region, a tendency towards a gradual increase in fertility rates was observed with the proportion of children of pre-school and school age increasing noticeably. In this regard, there is a need to increase the number of pre-school, general secondary and extra-curricular institutions in the region. As a result, there is a growing demand in educators, teachers, social educators, psychologists, speech therapists, and organizers of children's and youth creativity. This demand is also due to the natural aging of teaching staff, certain migration processes and changes in the professional orientations of the younger generation. The task of expanding the regional market of pedagogical work, increasing its diversity in line with the changing socio-demographic situation, is first of all solved by the professional pedagogical HEI.

3. State of health of the population. In spite of the moderately continental climate with mild winters and warm summers and the proximity of the Carpathians, the consequences of the Chernobyl accident, the ecological catastrophe in Stebnyk - the largest deposit of potassium salts in Ukraine, the barbaric exploitation of Borislav oil deposits, and other unfavorable natural and man-made factors require systematic introduction of health preserving technology for educating children and young people. Therefore, modern schools require specialists in the field of

\footnotetext{
Дрогобицький район : статистична інформація Головного управління статистики у Львівській області. URL : https://www.lv.ukrstat.gov.ua/ukr/si/ oper/2019/t180119_1.pdf
} 
inclusive education for working with children with special educational needs, specialists in defectology, social work, adaptive physical education, rehabilitation, etc. In this area, the pedagogical HEI is objectively a monopolist for the preparation of these categories of qualified specialists.

4. Migration processes and socio-cultural development of the region. On the one hand, low living standards in the Drohobych area account for the outflow of an active part of the population to other regions of Ukraine, near and far abroad, on the other hand, the region became an attractive destination for population migration from the occupied territories of Crimea and the East of Ukraine. The maintenance of the balance between the outflow and the influx of the population is accompanied by a gradual but significant change in the ethnic, religious, socio-cultural structure of the population of the region. Therefore, the teachers themselves are called to solve the problem of non-conflict intercultural communication, to form social tolerance in students, to level the language barrier in education, etc. The development of these specific professional competencies is possible only due to changes in the approaches to professional training of pedagogical personnel. Pedagogical HEI in the region is intended to solve the practical tasks of developing and implementing social and psychological and pedagogical technologies for the education and upbringing of children and young people in a multicultural society.

5. Socio-economic development of the region. The need to develop a science-intensive, efficient economy, modernization of industries, agriculture and services, computerization of production, logistics and infrastructure puts high demands on the quality of professional training of the skilled personnel. The level of this training primarily depends on the quality of the general secondary education of the future specialist as a result of the work of a qualified teacher. Therefore, pedagogical education in the region is a system-forming factor for the formation and development of the regional labor market. The presence of a pedagogical HEI, on the one hand, enables the preservation and improvement of the system of 
general secondary education, on the other hand, serves as a stabilizer and catalyst for the socio-economic development of the region.

Given the above facts, which are mostly typical for other regions of Ukraine, the risk of losing its main profile by pedagogical education, its subordination to classical universities is assessed as a risk of loss of subjectivity of regions in the socio-cultural and economic space of the state.

The analysis of the hypothetical scenario where pedagogical HEI in the region lose their main profile shows that the consequences in the near future may be manifested in such socio-economic processes, which are undesirable for the development not only of Drohobych area, but also of Lviv region as a whole: 1) a decrease in the quality of labor market resources in the region; 2) imbalance of deficit and surplus of pedagogical staff in the system of pre-school, general secondary and vocational education, and hence - imbalance between demand and supply in the regional market of educational services; 4) reduction of the potential development of the educational and general educational cluster in Lviv region, and the quality of the professional training of pedagogical staff, which may lead to a general re-orientation of the education system; 5) violation of functioning of the system of continuous pedagogical education and adherence to the principle of "education throughout life"; 6) loss of potential of development of social, spiritual and cultural sphere of the region; 7) systemic deterioration of the migration situation in the form of: the outflow of the most qualified teachers in other regions and neighboring countries; departure of young people from the region to receive a vocational education on popular or desirable profiles; reduction of the number of qualified pedagogical staff in rural areas in connection with the closure of small-scale schools; mass transfer of families to cities in order to get children more high-quality general and vocational education; 8) the growth of social tension, increasing the conflictrelatedness of the population of the region, increasing the number of 
groups of people with socially deviant behavior; 9) increasing barriers to the availability of high-quality secondary, vocational and higher education in the region and as a consequence - reducing the quality of human potential of the population and labor resources of the Lviv region; 10) the loss of the role of Lviv region as one of the leading centers of psychological and pedagogical sciences in Ukraine (for example, 2016 liquidation of the Lviv Scientific and Practical Center of Vocational Education of the National Academy of Sciences of Ukraine).

The experience of combining HEI, as a rule, based on classical universities, clearly demonstrates the reality of these consequences. It is no coincidence that pedagogical education as an integral part of the sociocultural space of the region remains an independent educational cluster. Almost all the regions where the merger of HEI (Zhytomyr, Kryviy Rih, Cherkassy, Chernivtsi, etc.) has taken place, maintain pedagogical education as an independent branch of higher education, taking into account the special socio-cultural significance of this educational cluster in the development of the region.

On the other hand, the most optimal way to solve the urgent tasks of reforming pedagogical education in the region is to strengthen the basic profile pedagogical HEI. The main areas of activity of Drohobych Ivan Franko State Pedagogical University (DSPU) are the following: training of highly-skilled specialists for the education system and other branches of the economy of Ukraine; retraining of specialists and improvement of professional skills of educational institutions of educational institutions and pedagogical workers; development, publication of educational and teaching-methodical literature; organization and conducting of fundamental and applied researches; preparation of scientific and pedagogical personnel of higher qualification; integration of the university into the European higher education system ${ }^{6}$.

\footnotetext{
${ }^{6}$ Дрогобицький державний педагогічний університет імені Івана Франка: літопис 2018 року / укл. Юрій Кишакевич. Дрогобич : PBВ ДДПУ, 2019. 223 c. URL : http://dspu.edu.ua/wp-content/uploads/ 2019/05/1-2018-st-016-037.pdf
} 
DSPU as an effective IV level of accreditation HEI with almost eighty years of history and tradition has a number of significant advantages that allow it to remain the nucleus of the educational cluster of the region ${ }^{7}$ :

1. Territorial-administrative. DSPU has a favorable geographical and geographical location that provides attractiveness for consumers of pedagogical services in Lviv, Ivano-Frankivsk and Zakarpattya regions. Transport accessibility of Drohobych due to the proximity of international routes reduces the territorial barrier on the way to obtaining high-quality higher education. The location of the HEI allows for operational interaction with the executive authorities of the region, ensuring the mobility of management decisions.

2. Material and technical. DSPU has a developed logistical and informational and resource facilities, therefore it is the center of cluster development of the whole system of education of the region. The training of future teachers is held in eight educational buildings with a total area of $43,101.63 \mathrm{~m}^{2}$, of which: classrooms, lecture halls, offices, laboratories $17,419.83 \mathrm{~m}^{2}$, computer classes $-906,90 \mathrm{~m}^{2}$, sports halls $-1,152,20 \mathrm{~m}^{2}$, premises for scientific and pedagogical workers $-1759,50 \mathrm{~m}^{2}$, dormitories $25,558,80 \mathrm{~m}^{2}$, dining rooms and buffets $-795,30 \mathrm{~m}^{2}$, medical center $96,60 \mathrm{~m}^{2}$, preventive and recreation centers $-2350,50 \mathrm{~m}^{2}$, etc.

The University has one of the most up-to-date scientific and educational libraries with an area of $2223,80 \mathrm{~m}^{2}$, consisting of 4 sections, 10 reading rooms for 350 seats $\left(438,60 \mathrm{~m}^{2}\right)$, two bookshops, a reference and bibliographic department, a collection and processing department literature, department of information technologies and computer software of the library. The total number of funds is about 700 thousand units, including: 299 thousand copies of educational literature, 297 thousand scientific publications, 99 thousand copies of fiction. Of particular value is the fund of rare editions, which has 1300 copies. Annually the library

\footnotetext{
${ }^{7}$ Інформація про наукову та науково-технічну діяльність Дрогобицького державного педагогічного університету імені Івана Франка за 2018 рік. URL : http://dspu.edu.ua/science/info-about-science-technicactivity
} 
receives 12,000 publications, serves about 9,000 users and issues 665,000 documents.

3. Structural and functional. The structure of the DSPU allows us to fully carry out the functions of training and professional development of the teaching staff of the region. Hence, about $80 \%$ of specialists involved in the education system of the region are graduates of Drohobych higher education.

As of January 1, 2019, there are four educational and scientific institutes (physics, mathematics, economics and innovative technologies, foreign languages, music, physical culture and health), five faculties (psychology, pedagogy and social work; philological, historical, biological and natural, primary and artistic education), postgraduate education center and pre-university training. At 42 departments of the University there are specialists from 12 branches of knowledge in 38 specialties at the first (bachelor), second (master) levels of higher education and educational qualification level of a specialist. In general, 5160 students study at the university (3,231 - full-time and 1,929 - in correspondence form of study).

4. Scientific-organizational. As of September 1, 2018, the teaching personnel of the DSPU consisted of 537 scientific and pedagogical workers, of which: doctors of sciences, professors - $67(12,4 \%)$, candidates of sciences, associate professors - $340(63,3 \%)$, without scientific degrees and titles - $130(24,3 \%)$. Compared to 2017 , the qualitative indicator of the scientific and pedagogical composition of the university grew by $10,2 \%$. There are postgraduate and doctoral programs in the DSPU, in which the specialists of higher scientific qualification are trained: at the third (educational-scientific) level - doctors of philosophy in 6 branches of knowledge, 13 specialties, 19 specialties (93 graduate students) and doctorates in 5 scientific specialties (6 doctorate). Since 1997, more than 200 postgraduate students and 6 graduate students have successfully defended their dissertation theses. 
There are three specialized academic councils at the DSPU: D 36.053.01 - for the defense of doctoral and master's theses in the specialty 13.00.01 - general pedagogy and history of pedagogy (in 2018 4 doctoral dissertations and 8 candidate's theses were defended); K 36.053.02 - for defense of candidate's theses in the specialty 10.02.01 Ukrainian language (in 20182 theses have been defended); K 36.053 .03 for defense of candidate's theses on specialty 07.00.06 - historiography, source study and special historical disciplines (in 20184 theses were defended).

5. International. The international cooperation of the DSPU covers 20 countries: Austria, Azerbaijan, Belgium, Belarus, Bulgaria, United Kingdom, Egypt, Italy, Kazakhstan, Lithuania, Moldova, Germany, Poland, Russia, Romania, Slovakia, USA, Hungary, Czech Republic and Japan. As of January 1, 2019, 46 international agreements are being implemented. The main directions of international cooperation include: joint activities on the problems of educational, methodological and research work; exchange of experience in certain areas; introduction of innovative training programs; exchange of scientific and pedagogical workers in order to intensify educational and research activities, internships, participation in scientific conferences; preparation of joint publications on conducted scientific and scientific-methodological researches; exchange of scientific and educational literature; exchange of experience in the organization of the educational process and training programs in related fields; development and coordination of masters' study programs within the framework of the "Double Diploma" project; exchange of students (study, practice, student scientific conferences); realization of joint research projects, including international grants; participation in creative competitions and festivals, etc.

The University actively participates in the ERASMUS + mobility program, in particular: the projects on "Student mobility of individual students and teaching staff of HEI between participating countries and 
partner countries" (Erasmus + KA1) with Lublin Catholic University and Rzeszow University (Poland) have been successfully completed; within the framework of the "Erasmus + KA 107" program, cooperation with the KATNO Higher School (Kottrike, Belgium) and Krakow University of Economics (Poland) are in progress; a joint international project with the European Union is being held on "Integration of the scientific environments of the Polish-Ukrainian border area (Poland-Belarus Ukraine)".

There is an active exchange of students with educational institutions in Austria, Poland, Belgium, within the bounds of the scientific curriculum of students (Maria Curie-Sklodowska University in Lublin, Poland), campus studies (Vienna Pedagogical Institute, Austria), the "Double Diploma" program (Polonium Academy in Czestochowa, Poland), practices of social teacher (University College VIVES, Belgium), summer school of the Ukrainian language for Austrian students with the participation of Drohobych students (Vienna - Lviv). 29 teachers and 78 students of the DSPU have taken part in international scientific-practical conferences, competitions, competitions and educational projects.

6. Innovative. DSPU is the center of scientific and methodological support for the regional education system, the center of integration of pedagogical and general educational institutions into a single complex, organized on the principles of continuous education. The university implements combined curricula with pedagogical colleges, technical schools and higher vocational schools in the region. The mobile training and retraining system of pedagogical staff is based on theoretical principles and practical recommendations of the School of Management Education Development. Today, an innovative model is being tested which aims at organizing the cluster interaction of the university as a center with institutions of vocational education, secondary schools and other educational and cultural institutions of the region. 
7. Social. The development of pedagogical education on the basis of effective HEI ensures its attractiveness for students, broadens the sociocultural possibilities of students, and allows the university to meet the multi-disciplinary educational needs of young people. The functioning of the DSPU in the socio-cultural space of the region greatly contributes to maintaining social stability, preventing social deviations, reducing the risks of social conflicts in the youth environment and the general population.

The functioning of the specialized pedagogical HEI in the Carpathian area will allow the region to reveal its potential as a major educational and cultural center and cross-border territories. Further increase of priority scientific-intellectual, personnel, information-communication, material and technical resources will facilitate to determine and effectively implement directions of modernization of the system of pedagogical education taking into account the specifics of the innovative socio-economic development of the region. The integration of pedagogical education in the Carpathian region with Drohobych State Pedagogical University as a center is oriented on the specific socio-economic problems of the region's development. Creation of a regional educational and pedagogical cluster will allow: 1) to reduce the deficit of teaching staff in the system of pre-school, general secondary, extra-curricular and vocational education of the region; to provide market of pedagogical work of the region and, first of all, rural school, highly skilled teaching staff; 2) to stabilize the migration situation in the region, connected with the obtaining of competitive profile pedagogical education; to minimize the outflow of the most qualified scientific and pedagogical workers and school graduates to other regions and neighboring countries; 3) to improve the quality of training of pedagogical staff through the development of professional competences and scientific level of teachers of the DSPU, introduction of innovative technologies in the process of training and education, the use of practical experience accumulated by the team of pedagogical HEI; 4) to develop a regional educational and pedagogical cluster at the expense of provision of 
educational, methodological, scientific, psychological and pedagogical, organizational, methodological and informational support of educational process in educational institutions of the region; 5) to preserve the system of continuous pedagogical education in the region, to provide the possibility of qualitative retraining and professional development of pedagogical workers around the DSPU; 6) to develop inclusive, special education in the region, to provide educational needs of groups with limited physical and material capabilities; 7) to implement professional psychological and pedagogical support for the socialization of children and youth in order to preserve their physical, mental and social health.

Thus, the analysis of the problem shows that increasing the efficiency of the functioning of the system of pedagogical education and, as a consequence, the impetus of socio-economic development of the region is connected with the preservation of the basic profile pedagogical HEI and its active innovative activity.

The mission of the regional pedagogical university ought to be directed at reproducing the intellectual potential of the region and its effective use to improve the quality of life of the population of the territory, and the basic principles of its organization should be the following: 1) the principle of purposefulness - provides the justification of the goals and priorities of the regional pedagogical university (training highly-skilled personnel to meet the needs of the regional educational industry and the economy; transformation of the HEI into educational, scientific and innovative complex, the transition from "preservation" of traditional scientific schools of the university to their active development, ensuring reproduction and raising the intellectual potential of the region); 2) the principle of consistency - involves the definition of goals, taking into account the relationship of educational, scientific and innovative activities with all sectors and spheres of life of the region; 3) the principle of integrity - involves the achievement of such a composition and content of the structural units of the university of pedagogy, proportions and 
relationships between them, which are intended to provide a balanced system of activities aimed at achieving the goals; 4) the principle of efficiency - involves the achievement of the goals set at the lowest cost; 5 ) the principle of adaptability - provides for an adequate response to the current and future needs of regional education, culture and economy; 6) the principle of balance of interests - involves the search for a consensus among all participants in the process of forming a new quality regional pedagogical university.

Preservation and development of the regional pedagogical university on the basis of these principles is an actual task of the present, the solution of which will allow mobilizing the intellectual potential of the region and ensuring its innovative socio-economic uplift.

Today, the competitiveness of any organization, enterprise, institution, institution directly depends on the ability to continuously develop and innovate. To the same extent, the competitiveness of the region on the national market, or the competitiveness of the country on the world, depends on the ability to continuously generate and innovate. The ability to innovate depends, above all, on the innovative potential of people, for the creation of which a largely responsible system of higher university education. On the one hand, the university is called to become the generator of new knowledge leading to innovation; on the other hand, to prepare skilled, competitive personnel with a high innovation potential. It should become a concentrator and a center for new knowledge and nuclei of the crystallization of innovation development, technology transfer, the launch of innovative ideas in various sectors of the national economy of the region. In addition, the university should be considered as a creative environment, whose socio-cultural function is to produce new knowledge and values, to create concepts, theories, methodologies, technologies, and information. 


\section{Strategic Development Program of Drohobych \\ Ivan Franko State Pedagogical University}

The mission of Drohobych Ivan Franko State Pedagogical University, as the generator of the innovative socio-economic development of the region, is aimed at the implementation of the following main components:

1) educational - to develop an innovative, which corresponds to world standards, a system of training of qualified pedagogical staff, competitive in the market of educational services, focused on self-realization, civic values and social responsibility;

2) scientific - to train the personnel of higher scientific qualification, to develop psychological and pedagogical research in the priority directions;

3) cultural - to be the center of culture in the region, helping to change the social environment, creating a certain spiritual atmosphere, teaching intellectual and constructive solution of problems, creative approach to realization of models of life, combining material and spiritual components at all stages of human life;

4) innovative - to be the leading scientific-coordination center for the development of the innovative environment of the region and the formation of a special innovation culture and innovations in it as a way of thinking and everyday activities.

In order to carry out this mission, it is necessary above all to work out a strategic program to be implemented in the following areas:

1. Organizational development of the university:

- development of the university organizational structure taking into account the principles of project management;

- creation of a network information and analytical system for making managerial decisions and reporting, developing new management technologies;

- ensuring the full-scale functioning of the quality management system as a mechanism for monitoring and optimizing management processes; 
- update of the local normative base of the university in connection with the change of organizational-legal form (autonomy);

- development of the university management system for improving the conditions of professional activity and social conditions of scientific and pedagogical workers and students;

- adaptation of the organizational structure of the university to solve strategic tasks of an innovative nature;

- a combination of mechanisms for solving tactical tasks in the management of the university with a program for its strategic development through the medium and short-term planning mechanism and the system of balanced indicators;

- development of the corporate information system and network infrastructure, integrating data sources and information flows of all structural entities of the university complex, as well as aspects of their activities;

- improvement of the system of support and management of management decisions on the basis of resource monitoring, control of actual distribution and evaluation of the efficiency of their use;

- improvement of normative documents regulating the use of personnel, financial, information and material and technical resources in order to ensure effective management of the university.

2. Development of personnel potential:

- development of corporate culture, economic incentives and social guarantees in order to create conditions for the most complete selfrealization of scientific and pedagogical workers and students and maximum satisfaction with work and study;

- development and implementation of a program for the reproduction and development of human resources that involves DSPU's participation in the teaching and scientific activities of the most talented, competent graduates and graduate students, as well as creative specialists in the field of educational activities; 
- development of long-term relations with leading foreign scientific and educational centers in the form of academic exchanges;

- internships of teachers, post-graduate students and doctoral students of the university;

- involvement of foreign scientists and practitioners in the scientific and educational activities of the university;

- development and commissioning of a permanently updated system of requirements for the competitive selection of faculty members taking into account the innovative approach to educational activities, systematic participation in research work of an innovative nature, publications in international scientific-metric databases, obtaining degrees and degrees, attracting students to performance of scientific research, their effectiveness and other indicators;

- increasing requirements for all categories of employees (administrative, managerial, teaching and support staff), their professional level and degree of qualification, the possibility of developing new information technologies and methods of organizing the educational process;

- formation of a personnel reserve of the leading staff of the university, structural units, as well as a pedagogical and scientific reserve;

- development of mechanisms for the implementation of targeted social support of scientific and pedagogical staff of the university:

- targeted support of leading scientific and pedagogical schools,

- development of a university-wide grant system for young teachers, postgraduates and doctoral students;

- provision of guarantees of labor rights and freedoms of scientific and pedagogical workers, creation of favorable working conditions, protection of their rights and interests, as well as provision of guarantees of compliance with the requirements of safe work and social insurance;

- development of social infrastructure objects, their modernization, reconstruction, construction of new objects; 
- increasing the efficiency of using social infrastructure and sports facilities to maintain a healthy lifestyle and raise the cultural level of scientific and pedagogical workers and students;

- expansion of the range of measures to ensure the protection of the rights of scientific and pedagogical workers and students by including them in collective agreements with the administration of the university;

- provision of participation of scientific and pedagogical workers and students in the management of the university through public and trade union organizations;

- raising the professional qualification level of the faculty as a condition for ensuring high quality education, research and compliance with licensing requirements.

3. Development of educational activities:

- gaining leading positions in the training of future teachers through the improvement of the system of vocational education through the wide introduction of new technologies and strengthening the integration of the educational process, research and innovation activities, as well as through the development of a multi-level system of continuing vocational education using modern information and communication technologies, in $\mathrm{t}$ distance education;

- strengthening the position of the university as an innovative research center of competence in the field of educational and information technologies, achievement of the status of the leading scientific and educational center;

- support and development of the university of innovative educational environment in order to prepare competitive educators able to develop the market of educational services in priority areas for the region;

- expansion of the spectrum of educational programs; an increase in the proportion of targeted contractual training, the active participation of the university in the development and implementation of targeted regional development programs in terms of staffing; 
- development of project training of students based on innovations and cooperation in the interests of educational institutions and institutions of the region;

- development and improvement of innovative educational technologies using the principles of continuous graduate education: preuniversity training, basic higher education (bachelor, master), basic scientific education (doctor of philosophy, doctor of sciences), continuing education (second higher education, advanced training and professional retraining, additional qualification);

- use of the information and communication network for the full access of students and teachers to the combined information resources of Ukraine and the world information environment, as well as for the introduction of educational systems based on the latest information technologies;

- introduction of full-time distance learning through the use of resources of the scientific library, including in the implementation of additional educational services (second higher education, additional qualifications, etc.);

- development and improvement of the quality management system at the university; provision of regular internal and external quality audits of educational-professional and educational-scientific programs and educational disciplines;

- organization, in conjunction with the departments and departments of the region's education, to monitor the needs of pedagogical staff with the task of identifying priority areas and levels of training and retraining of specialists, expanding the range of new specialties; creation of a system for analyzing the needs of educational programs and graduates of the educational institutions of the region, establishing long-term partnerships with public and private providers of educational services;

- expansion of interaction with major domestic and foreign universities; conclusion of agreements that provide for the exchange of students, postgraduate students and teachers; 
- strengthening of the university's position in the international market of educational services by improving educational-professional and educational-scientific programs, their international accreditation;

- increasing the academic mobility of teachers, students, postgraduates, doctoral students through the expansion of international exchanges; providing more opportunities for students to study foreign languages (especially English);

- intensive development of informational support of the educational process, achievement of full availability of modern educational, methodical and scientific literature, as well as electronic resources;

- creation of an effective system of staffing of the educational process of the university; improvement of the educational load planning system and teachers payments through optimizing the educational process by the criterion "quality -expenses"; development of new mechanisms for funding educational activities of structural units;

- completion of the transition to a credit transfer organization of the educational process with nonlinear asynchronous individually directed educational trajectories.

4. Development of scientific activity:

- integration of research and innovation activities with the educational process;

- improvement of the mechanism of attraction and effective use of budget and extra-budgetary funding for achievement of high scientific results; development of material and technical base of scientific research;

- expansion of interaction with regional authorities, educational institutions, scientific institutions, enterprises of various forms of property, etc., with the purpose of orientation of scientific researches on tasks and problems of the region; establishment of an expert center for analysis of economic, scientific and technical and socio-cultural development of the region on the basis of the university; 
- improvement of the effectiveness of postgraduate and doctoral management; expanding the range of specialties of post-graduate and doctoral studies in accordance with modern problems of innovative economy, priority scientific directions in psychology and pedagogy; development of extra-budgetary forms of training for postgraduate and doctoral students;

- expansion of specialized scientific councils for the protection of dissertations from various scientific specialties; improvement of organizational and material basis of activity of specialized academic councils;

- pursuit of a purposeful personnel policy for the preparation and consolidation at the university of scientific personnel of the highest qualification;

- development of advanced foreign scientific experience through participation in international scientific programs, internships and exchanges of specialists; creation of scientific centers and laboratories intended to provide permanent cooperation with foreign partner universities; broad involvement of young scientists, undergraduate and graduate students to this process;

- creation of an effective system of stimulation of teachers and employees for the high results of scientific work and improvement of domestic and international scientific and metric indicators.

5. Development of innovation activity:

- formation of the developed innovative infrastructure of the university, including the promotion of the creation of small high-tech enterprises on the basis of the university;

- activation of innovative entrepreneurship, expansion of the practice of creating a university of various forms of business associations;

- implementation of the system of measures to support the inventive and innovative activities of university staff and students; 
- development of innovation activities related to the introduction and promotion of the intellectual property market belonging to the university;

- stimulation of innovative activity of structural units, employees and students of the university, as well as small innovative enterprises created on the basis of higher education;

- priority development of research at the university aimed at technological modernization of the real sector of the region's economy;

- comprehensive support for the commercialization of research results of structural subdivisions, university staff and students;

- development of the applied research base of the university, expansion of applied research in the interests of development of priority sectors of the region's economy;

- facilitation of formation, preparation and promotion of innovative, scientific and technical projects and programs of the University regarding promising areas of science and technology;

- ensuring interaction between the university's academic departments and business partnerships established at the university with the aim of introducing into their own scientific and technological developments;

- support of the activity of structural subdivisions of the University aimed at the development and production of high-tech products, as well as the provision of scientific, technical and educational services;

- comprehensive interaction with state and public organizations, funds for the development of scientific activity of individual employees, students, as well as structural subdivisions of the University;

- formation of a system of sustainable innovation-oriented relations, long-term programs of scientific and technical cooperation between the university, other educational institutions, enterprises and organizations of various forms of ownership;

- development of cooperation with enterprises of the real economy sector for the organization of joint educational programs with the involvement of leading specialists, the use of material and technical potential and resources of enterprises of the region in the educational process; 
- increase of students' participation in applied research for the practical realization of fundamental scientific knowledge gained during the learning process.

\section{Development of extra-curricular activities:}

- creation of conditions for active life, maximal satisfaction of students' needs in intellectual, cultural, spiritual, moral and physical development;

- identification and development of creative potential of students, their involvement in national culture, formation of value orientations, patriotism, stable moral principles and norms, adherence to the chosen profession, strengthening of active life position;

- raising students' aspirations for work, healthy lifestyle, zerotolerance attitude to drugs, drinking, anti-social behavior; creating conditions for the formation of healthcare-retaining competence in the student environment, increasing the number of students involved in systematic promotion of a healthy lifestyle; formation among students of a conscious negative attitude towards all types of dependence;

- strengthening cooperation with regional organizations and medical institutions that carry out preventive work;

- formation of the physical culture of the student's personality and the ability to purposefully use various means of physical education and sports in order to preserve and strengthen health, psychophysical training and self-training for future professional activities;

- formation of students' needs for self-development, skills and abilities of collective management in various forms of student selfgovernment;

- ensuring the interaction of the bodies of student self-government with the leadership of the university, government bodies, public associations, etc.; development of student initiatives and involvement of future specialists in various forms of social activity; 
- provision of socio-psychological support to students, adaptation of freshmen and non-resident students to new learning conditions in order to harmoniously enter the university environment.

\section{Informatization and telecommunication development:}

- consolidation of scientific and innovative potential in the field of information technologies and telecommunications; organization of the development and implementation of specific applications for educational, industrial and other organizations in the region;

- creation of training and retraining system based on authorized courses in cooperation with leading software firms (Microsoft, Oracle, IBM, etc.);

- creation of technical conditions for the development and introduction of centralized electronic document management system at the university;

- implementation of a complex of works on the creation and operation of a single educational environment in the region;

- participation in the creation of the scientific and technical council on informatization of the region;

- creation of a service for innovation in the field of information technologies and a regional resource center of a single educational information environment (with the involvement of the departments of economic cybernetics and innovation and innovative systems and technologies);

- creation on the basis of the university of a regional educational network and services of its information content and technical support.

8. Development of international activity:

- development of international cooperation in the field of higher education, increase of academic mobility of students and teachers;

- international accreditation of educational-professional and educational-scientific programs, expansion of the range of directions of the program "Double diploma". 
9. Development of material and technical base:

- development and phased implementation of the program for the updating of educational, production, research and economic equipment;

- expansion of the area for educational, scientific, social, nonacademic, economic activities through the completion of major repairs and commissioning of new infrastructure objects;

- implementation of a program aimed at creating decent and safe learning environment for students living in hostels.

10. Development of financial and economic activity:

- expanding possibilities of attraction of funds, diversification of sources of financial resources;

- multivariate financial resources at the expense of different sources;

- systematic analysis and control of financial flows, objective justification of cost estimates, timely adjustment of budget descriptions;

- improvement of the system of remuneration of the university staff and their material incentives;

- development of a system of interconnection of planning, attraction and rational use of extra-budgetary funds;

- economy of financial resources of the university;

- expansion of the spectrum of paid educational, consulting, service and other types of services;

- active involvement of charity and sponsorship funds, creation of a university development fund.

11. Development of marketing activities:

- increase of university revenues from the implementation of basic and additional educational programs due to deeper penetration of the regional, domestic and international markets of educational services;

- improvement of the conditions for the development of the system of job placement and adaptation to the labor market of graduates of the university; 
- coordination of the activities of the structural units of the university, aimed at creating and implementing a system of employment promotion for university graduates;

- further development of the system of interaction of the university with partners-employers in the field of employment of future teachers;

- organizational and methodological development of the university's marketing activities (with the involvement of the Department of Management and Administration).

\section{SUMMARY}

Consequently, a modern pedagogical university, acting as the center of science, culture and education in the region, solves a complex of diverse tasks, the most important of which are stabilization and development of the territorial system of education, aiming at the innovative development of the region and meeting the educational needs of its population. The proposed principles, strategic program, directions and mechanisms for its implementation serve as an innovative model that involves organizational restructuring and transformation of the pedagogical university into a multistage, flexible, open and self-sustaining institution of higher education, which will contribute to the growth of the positive socioeconomic dynamics of the region's growth.

\section{REFERENCES:}

1. Дрогобицький державний педагогічний університет імені Івана Франка: літопис 2018 року / укл. Юрій Кишакевич. Дрогобич : РВВ ДДПУ, 2019. 223 с. URL : http://dspu.edu.ua/wp-content/uploads/2019/ 05/1-2018-st-016-037.pdf

2. Дрогобицький район : статистична інформація Головного управління статистики у Львівській області. URL : https://www.lv.ukrstat.gov.ua/ukr/si/ oper/2019/t180119_1.pdf 
3. Інформація про наукову та науково-технічну діяльність Дрогобицького державного педагогічного університету імені Івана Франка за 2018 рік. URL : http://dspu.edu.ua/science/info-about-sciencetechnic-activity/

4. Наконечна Т.Ю. Регіональна інноваційна політика як фактор зростання національної економіки. Теоретичні $і$ практичні аспекти економіки та інтелектуальної власності. 2010. Т. 1. С. 67-72.

5. Освіта в Україні: базові індикатори. Інформаційностатистичний бюлетень результатів діяльності галузі освіти у 2017/2018 н. $p$. URL : https://mon.gov.ua/storage/app/media/novaukrainska-shkola/1 serpkonf-informatsiyniy-byuleten.pdf

6. Регіональний розвиток та державна регіональна політика в Україні : стан і перспективи змін у контексті глобальних викликів та європейських стандартів політики : аналітичний звіт. URL : https://surdp.eu/uploads/files/ Analytical_Report_Main_part_UA.pdf

7. Ржепішевська В. В. Проблеми та перспективи функціонування вищих навчальних закладів у регіональній інноваційній системі. Ефективна економіка : електронний журнал. 2013. № 3. URL : http://www.economy. nayka.com.ua/?op=1\&z=1877\#

Information about the author:

Orshansky L. V.

Doctor of Pedagogical Sciences, Professor, Head of the Department of Technological and Professional Education, Drogobych Ivan Franko State Pedagogical University 4/6, M. Hrushevsky str., Drohobych, Lviv region, 82107, Ukraine 